\title{
Ichthyofauna of streams of the Rio Sapucaí basin, upper Rio Paraná system, Minas Gerais, Brazil
}

\author{
Valter M. Azevedo-Santos ${ }^{I^{*}} \mathbb{1}$, Heraldo A. Britski $^{2}$, Claudio Oliveira ${ }^{3}$ \& Ricardo C. Benine ${ }^{I}$ \\ ${ }^{1}$ Universidade Estadual Paulista, Instituto de Biociências, Botucatu, 18618-689, Botucatu, SP, Brasil \\ ${ }^{2}$ Universidade de São Paulo, Museu de Zoologia, Ipiranga, 04299-970 São Paulo, SP, Brasil \\ ${ }^{3}$ Universidade Estadual Paulista, Departamento de Morfologia, Laboratório de Biologia e Genética de Peixes, \\ 18618-000, Botucatu, SP, Brasil
}

"Corresponding author: Valter M. Azevedo-Santos, valter.ecologia@gmail.com

AZEVEDO-SANTOS, V. M., BRITSKI, H. A., OLIVEIRA, C., BENINE, R. C. Ichthyofauna of streams of the Rio Sapucaí basin, upper Rio Paraná system, Minas Gerais, Brazil. Biota Neotropica. 19(1): 20180617. http://dx.doi.org/10.1590/1676-0611-BN-2018-0617

\begin{abstract}
The Rio Sapucaí basin, in Minas Gerais State, Brazil, is one of the many watersheds of the upper Rio Paraná system. Ichthyofauna surveys in this basin, in general, are scarce. In addition, small rivers and streams of the region have been targets of anthropogenic actions (e.g., pollution) - which suggest that more ichthyological studies must be performed within the watershed. In this study we provide a survey of species that occur within three streams of the lower Rio Sapucaí basin. Samples were collected in April, July, and November 2017 and in May 2018. Collections resulted in 349 individuals belonging to 28 species, five orders, and 12 families. Among our findings are three putatively undescribed species and the first record of Oligosarcus argenteus and Pareiorhina hyptiorhachis within the Rio Paraná system.

Keywords: fishes; inventory; Oligosarcus argenteus; Pareiorhina hyptiorhachis; undescribed species.

\section{Ictiofauna de riachos da bacia do Rio Sapucaí, sistema do alto Rio Paraná, Minas Gerais, Brasil}

Resumo: A bacia do Rio Sapucaí, no Estado de Minas Gerais, Brasil, é uma das muitas bacias hidrográficas do sistema do alto Rio Paraná. Levantamentos de ictiofauna nessa bacia, em geral, são escassos. Além disso, rios de pequeno porte e córregos da região têm sido alvos de ações antrópicas (e.g., poluição) - o que sugere que mais estudos ictiológicos devem ser realizados na bacia. Neste trabalho nós fornecemos um levantamento de espécies que ocorrem em três riachos da porção baixa da bacia do Rio Sapucaí. As amostras foram coletadas em Abril, Julho, e Novembro de 2017 e em Maio de 2018. As coletas resultaram em 349 indivíduos pertencentes a 28 espécies, cinco ordens e 12 famílias. Dentre os nossos achados estão três espécies possivelmente não descritas e o primeiro registro de Oligosarcus argenteus e Pareiorhina hyptiorhachis no sistema do Rio Paraná.

Palavras-chave: espécies não descritas; inventário; Oligosarcus argenteus; Pareiorhina hyptiorhachis; peixes. 


\section{Introduction}

Ichthyofauna surveys are important for the conservation of freshwater fishes at both short and long-term scales. These studies provide additional information about species' distribution (e.g., Valdiviezo-Rivera et al. 2017, Bertora et al. 2018, Delariva et al. 2018, Honorio \& Martins 2018, Oliveira-Silva et al. 2018) - which, in turn, may assist in new assessments about their "conservation status" (e.g., Melo et al. 2017). Additionally, surveys provide useful data for the establishment of freshwater protected areas (sensu Azevedo-Santos et al. 2018a). Therefore, ichthyological surveys should be carried out more frequently, especially in Brazilian freshwaters.

The Rio Sapucaí basin ( 560,000 hectare; Magalhães Jr \& Diniz 1997), Minas Gerais, Brazil, is part of the upper Rio Paraná system (Magalhães Jr \& Diniz 1997). To our knowledge, only two ichthyological surveys have been published for this watershed. Ingenito \& Buckup (2007) provided a list with the fishes of three localities in the upper portion of the basin near the Serra da Mantiqueira. Subsequently, Belei \& Sampaio (2012) publishes a work with the fishes from the Rio Lourenço Velho, a direct tributary of the Rio Sapucaí. However, streams of the lower region of the watershed remain understudied.

Countless rivers and streams of the Rio Sapucaí basin have been targets of anthropogenic actions (e.g. small dams; see Belei \& Sampaio 2012), which can significantly impact the overall biodiversity (Pelicice et al. 2017). These actions coupled with the lack of biodiversity knowledge suggest that more surveys must be conducted within the watershed. In this study we provide the results of a fish survey conducted in three different streams of the lower portion of the Rio Sapucaí basin, in Minas Gerais, Brazil.

\section{Material and Methods}

Fishes were collected in April, July, and November 2017, and in May 2018 (totaling four collections, one per month), across three different streams of the Rio Sapucaí basin (Table 1; Figure 1-2). Sampling occurred during daytime roughly 100 to 200 meters upstream of each stream. Collections were carried out with a small cast net $(1.4 \mathrm{~cm}$ of mesh in opposite nodes), a hand net ( $\sim 1.5 \mathrm{~mm}$ mesh), gill nets ( 1 and 2 $\mathrm{cm}$ in opposite nodes), and fishhooks of different sizes. Collections were performed with permission issued by Brazilian Institute of Environment and Renewable Natural Resources (IBAMA, in Portuguese) - license numbers 46904-1 and 63177-1.

Vouchers specimens were euthanized with successive dosages of anesthetic, and transferred to a $10 \%$ formalin solution. Following fixation, individuals were transferred to a $70 \%$ alcohol solution and deposited at LBP (Laboratório de Biologia de Peixes, Departamento de Morfologia, Universidade Estadual Paulista "Júlio de Mesquita Filho", Botucatu, São Paulo, Brazil), DZSJRP (Departamento de Zoologia e Botânica, Universidade Estadual Paulista "Júlio de Mesquita Filho", São José do Rio Preto, São Paulo, Brazil), and LIRP (Laboratório de Ictiologia de Ribeirão Preto, Universidade de São Paulo, Ribeirão Preto, São Paulo, Brazil).

Species reported in Table 2 were classified according to Fricke et al. (2018).

\section{Results}

A total of 349 individuals representing five orders, 12 families, and 28 fish species (Table 2) were collected from all reaches (i.e., R1, R2, R3). The order and family with highest species richness, considering all reaches, was Siluriformes and Characidae, respectively (Figure 3-4). We found the highest species richness at R3, with a total of 23 species, followed by R1 with nine and R2 with seven (Table 3).

Three putatively undescribed species were also collected: Astyanax sp. and 'Heptapterus' sp., both from R1, and Imparfinis sp., from R3. Additionally, we found individuals of Oligosarcus argenteus and Pareiorhina hyptiorhachis, which represent the first record of these two species within the Rio Paraná system (Table 3). Individuals of Trichomycterus septemradiatus were collected at R1, which also

Table 1. Localities sampled from the lower Rio Sapucaí basin, Rio Paraná system, Minas Gerais, Brazil

\begin{tabular}{|c|c|c|c|c|c|}
\hline Reaches & Acronym & Coordinates & Altitude (meters) & Municipality & Remarks \\
\hline Reach 1 & R1 & $20^{\circ} 54^{\prime} 57.59^{\prime \prime} \mathrm{S}, 45^{\circ} 56^{\prime} 21.15^{\prime \prime} \mathrm{W}$ & $\sim 828$ & Carmo do Rio Claro & $\begin{array}{c}\text { Stream of unknown name. Affluent } \\
\text { of Ribeirão Itací, Rio Sapucaí } \\
\text { basin. Reach in the stream well- } \\
\text { preserved. Riparian vegetation } \\
\text { present. Reach with substrate, } \\
\text { in general, composed by rocks } \\
\text { juxtaposed. }\end{array}$ \\
\hline Reach 2 & $\mathrm{R} 2$ & $20^{\circ} 55^{\prime} 25.12^{\prime \prime S}, 45^{\circ} 58^{\prime} 21.63^{\prime \prime} \mathrm{W}$ & $\sim 783$ & Carmo do Rio Claro & $\begin{array}{l}\text { Stream of unknown name. Affluent } \\
\text { of Ribeirão Itací, Rio Sapucaí basin. } \\
\text { Reach in the stream with total (in } \\
\text { some local partial) absence of riparian } \\
\text { vegetation. Substrate composed by } \\
\text { sandy, rarely with some rocks. }\end{array}$ \\
\hline Reach 3 & R3 & $21^{\circ} 3^{\prime} 25.73^{\prime \prime S}, 46^{\circ} 8^{\prime} 47.10^{\prime \prime W}$ & $\sim 787$ & Conceição da Aparecida & $\begin{array}{l}\text { Stream known as Ribeirão Fortaleza, } \\
\text { Rio Sapucaí basin. Reach in the } \\
\text { stream with riparian vegetation } \\
\text { completely removed. Substrate } \\
\text { composed by sandy, with a local } \\
\text { composed by rocks. Some locals } \\
\text { impacted due the cattle breeding. }\end{array}$ \\
\hline
\end{tabular}




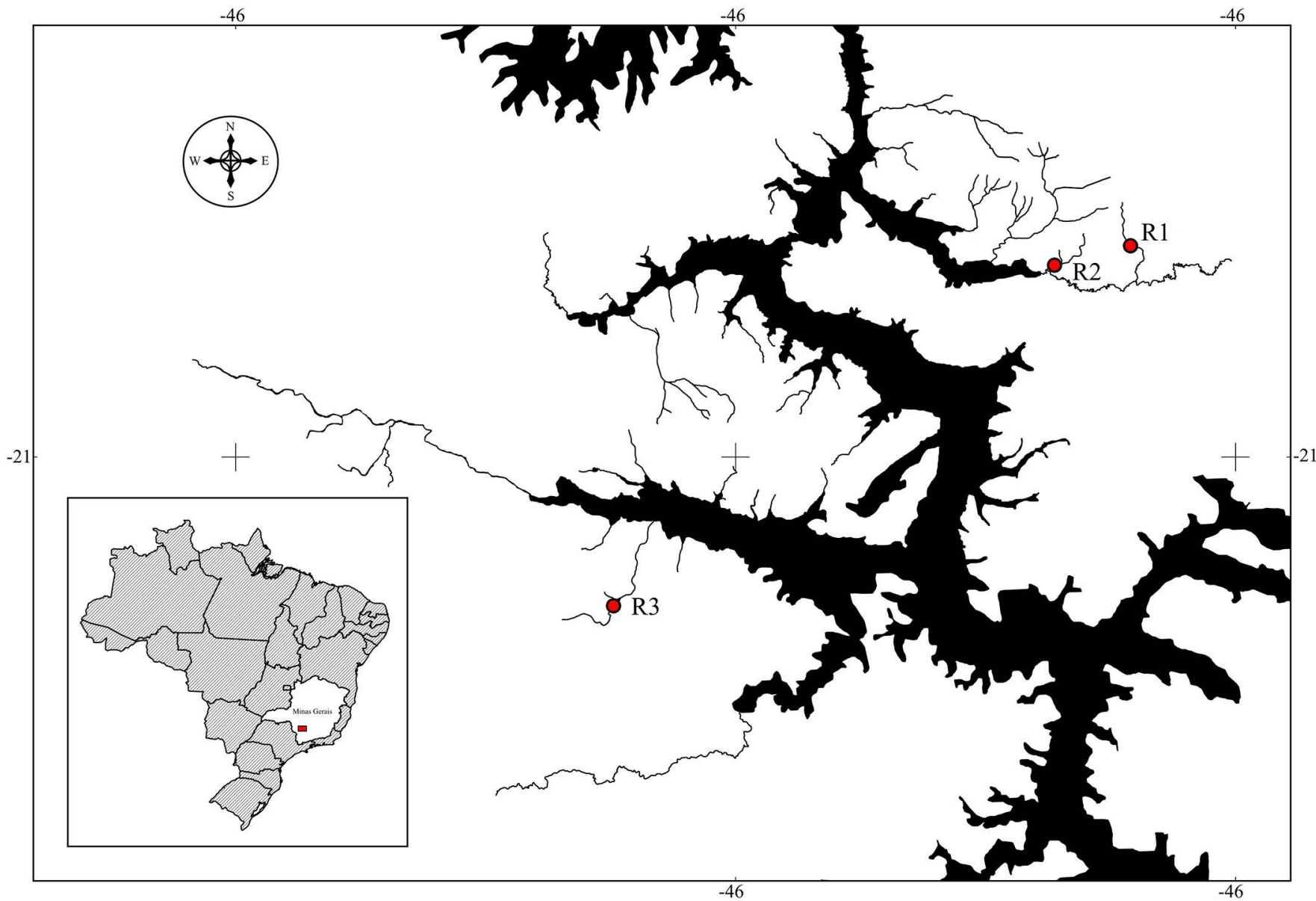

Figure 1. Partial view of Rio Sapucaí (under influence of the Furnas reservoir), in Minas Gerais, Brazil, with the location of each reach (R1, R2, and R3) sampled.

expands the distribution of this species into the Rio Paraná system. Lastly, we recorded Knodus moenkhausii and Poecilia vivipara, two non-native fish species within the Rio Sapucaí basin.

\section{Discussion}

Overall, members of the orders Siluriformes and Characiformes comprise the majority of species found in the three sampled streams of the Rio Sapucaí basin (see Figure 3). Dozens of investigators who have conducted fish surveys of rivers, reservoirs, or streams of the upper Paraná basin (e.g., Casatti et al. 2003, Smith et al. 2007, Smith \& Petrere Jr 2007, Fagundes et al. 2015, Frota et al. 2016, Santos et al. 2017, Cavalli et al. 2018) have also found species richness to be highest in these orders. Therefore, the relatively high species counts in these two orders, as we found in this study, is an expected result for many regions of the upper Rio Paraná system.

The families with highest species richness in the lower Rio Sapucaí region are Characidae and Heptapteridae. However, in context of the Rio Paraná basin as a whole, Loricariidae has been reported to contribute higher species richness than Heptapteridae (Langeani et al. 2007). This suggests that loricariid species may have been undersampled in this survey. Specimens were collected only during the day (see Material and Methods section), which may have contributed to an undersampling of loricariids and possibly other groups (see below). Therefore, for future studies we recommend sampling at each stream during the night as well.

Odontostilbe weitzmani Chuctaya, Bührnheim, \& Malabarba, 2018, a species recently described from the upper Paraná system (Chuctaya et al. 2018), has previously been collected at R1 (DZSJRP 20445, 2014 year). However, this species was not collected during this survey.

Three putatively undescribed species (i.e., Astyanax sp., 'Heptapterus' sp., and Imparfinis sp.) were collected during this survey (Figure 5a, b, c). In addition to this study, Ingenito \& Buckup (2007) discovered six undescribed species within the upper Rio Sapucaí basin. With these results we believe more ichthyological surveys in rivers and streams of the Rio Sapucaí basin are necessary, as additional undescribed species likely remain to be discovered.

Langeani et al. (2007) did not report Oligosarcus argenteus (Figure 5e) within the upper Rio Paraná system. Additionally, in a recent revision of the genus Oligosarcus, Ribeiro \& Menezes (2015) reported this species as endemic to the Rio São Francisco and Rio Doce basins. In turn, Pareiorhina hyptiorhachis (Figure 5f) was recently described from the Rio Paraíba do Sul basin (Silva et al. 2013). Our study reports individuals of $O$. argenteus at $\mathrm{R} 1$ and individuals of $P$. hyptiorhachis at $\mathrm{R} 1$ and $\mathrm{R} 2$. Therefore, these findings represent the first records of these two species in the Rio Sapucaí basin, as well as in the Rio Paraná system in general. 


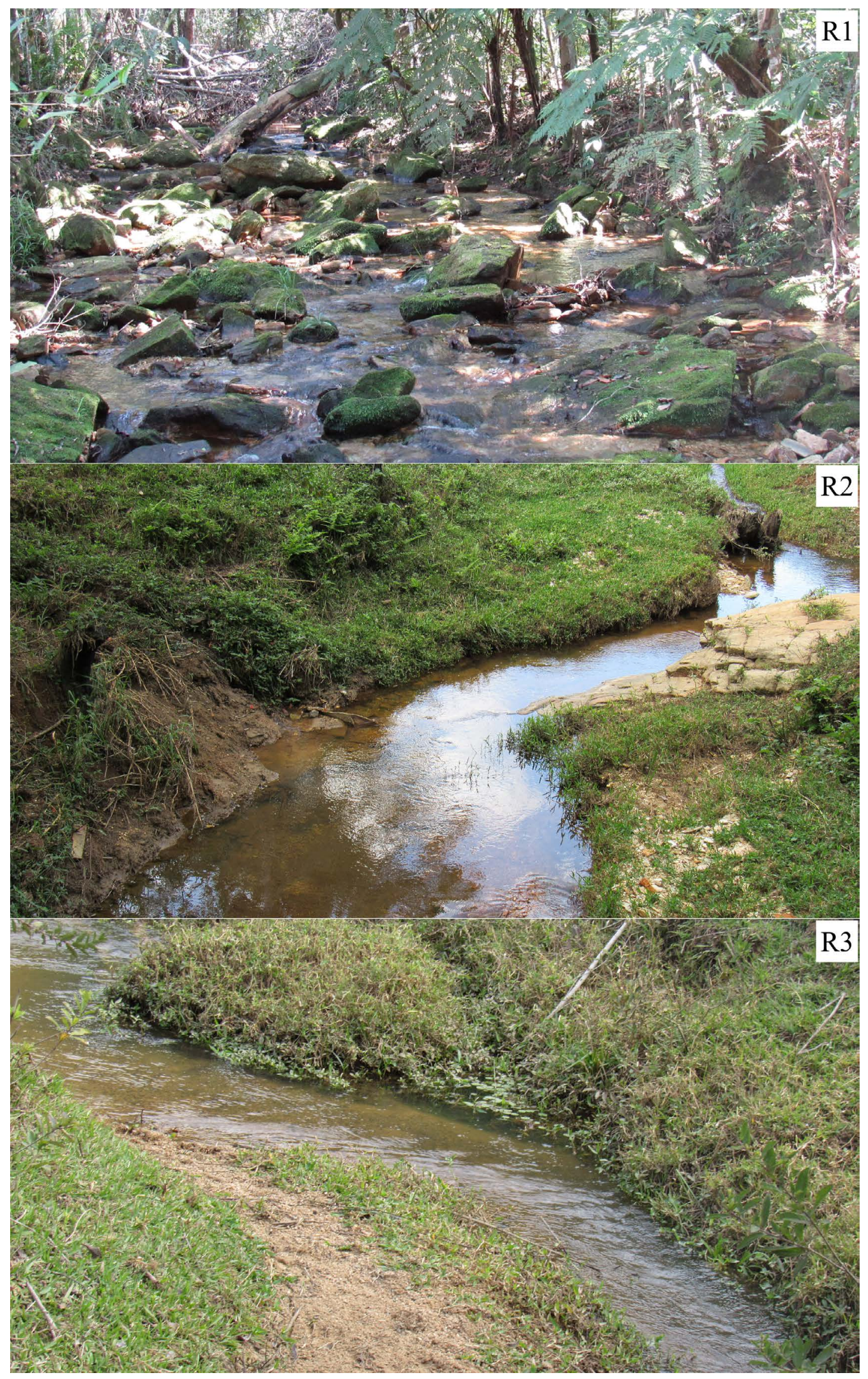

Figure 2. Partial view of each reach (R1, R2, and R3) sampled in streams of the Sapucaí basin, Minas Gerais, Brazil. 
Ichthyofauna of streams of the Rio Sapucaí basin

Table 2. Fish species captured in three reaches of streams of the Rio Sapucaí basin, upper Rio Paraná system, Minas Gerais, Brazil.

\begin{tabular}{|c|c|}
\hline SPECIES & VOUCHER \\
\hline \multicolumn{2}{|l|}{ CHARACIFORMES } \\
\hline \multicolumn{2}{|l|}{ Crenuchidae } \\
\hline Characidium gomesi Travassos, 1956 & DZSJRP 21136 \\
\hline \multicolumn{2}{|l|}{ Erythrinidae } \\
\hline Hoplias malabaricus (Bloch, 1794) & LBP 23576; LBP 23580; LBP 23592; LBP 26591 \\
\hline Astyanax fasciatus (Cuvier, 1819) & LBP 23600; LBP 26585; LBP 26587; LBP 26608 \\
\hline Astyanax lacustris (Lütken, 1875) & LBP 26586; LBP 26589 \\
\hline Astyanax sp. ${ }^{* *}$ & LBP 23573; LBP 26571 \\
\hline Knodus moenkhausii (Eigenmann \& Kennedy, 1903)*** & $\begin{array}{l}\text { DZSJRP 21131; LBP 26578; DZSJRP 21132; LBP 26583; LBP 26584; } \\
\text { LBP } 26605\end{array}$ \\
\hline Piabina argentea Reinhardt, 1867 & LBP 23601; LBP 26592; LBP 26611 \\
\hline
\end{tabular}

\section{GYMNOTIFORMES}

\section{Gymnotidae}

Gymnotus carapo Linnaeus, 1758

LBP 23597; LBP 26602

\section{Sternopygidae}

Eigenmannia cf. trilineata Lopez \& Castello, 1966

\section{SILURIFORMES}

Heptapteridae

Cetopsorhamdia iheringi Schubart \& Gomes, 1959

Rhamdia cf. quelen (Quoy \& Gaimard, 1824)

'Heptapterus' sp.**

Imparfinis schubarti (Gomes, 1956)

Pimelodella gracilis (Valenciennes, 1835)

Imparfinis sp.**

\section{Pimelodidae}

Pimelodus maculatus Lacepède, 1803

\section{Trichomycteridae}

Trichomycterus candidus (Miranda-Ribeiro, 1949)

Trichomycterus septemradiatus Katz, Barbosa \& Costa 2013

\section{Callichthyidae}

Callichthys callichthys (Linnaeus, 1758)

LBP 23595; LBP 26599

LBP 23574; LBP 26568; LBP 26574; LBP 26576; LBP 26582; LBP23599; LBP 26606

LBP 26609

LBP 23577; LBP 26570; LBP 26575

LIRP 14326; LBP 26601

LIRP 14327

LIRP 14325; LBP 26600

LBP 26594

LBP 23575; LBP 26567; LBP 26579; LBP 26581; LBP23596

LBP 23578; LBP 26569; LBP 26573; LBP 26577

LBP 23598; LBP 26603

\section{Loricariidae}

Hisonotus cf. alberti Roxo, Silva, Waltz, Melo 2016

LBP 23590; LBP 26593; LBP 26595

Hypostomus ancistroides (Ihering, 1911)

LBP 23594; LBP 26598

Pareiorhina hyptiorhachis Silva, Roxo, \& Oliveira 2013 *

\section{CICHLIFORMES}

\section{Cichlidae}

Geophagus brasiliensis (Quoy \& Gaimard, 1824)

LBP 23571; LBP 26566; LBP 26572; LBP23579; LBP 26580

LBP 23593; LBP 26588; LBP 26590; LBP 26597

\section{CYPRINODONTIFORMES}

\section{Poeciliidae}

Poecilia vivipara Bloch \& Schneider, 1801***

* First record for the upper Rio Paraná system.

** Putatively undescribed species.

*** Non-native species. 
AZEVEDO-SANTOS, V. M. et al.

Table 3. Species captured (X) in each reach of the three different streams, Rio Sapucaí basin, Minas Gerais, Brazil.

\begin{tabular}{|c|c|c|c|}
\hline \multirow[t]{2}{*}{ SPECIES } & \multicolumn{3}{|c|}{ REACH } \\
\hline & R1 & $\mathbf{R 2}$ & R3 \\
\hline Astyanax fasciatus & & $\mathrm{X}$ & $\mathrm{X}$ \\
\hline Astyanax lacustris & & $\mathrm{X}$ & $\mathrm{X}$ \\
\hline Astyanax sp. & $\mathrm{X}$ & & \\
\hline Callichthys callichthys & & & $\mathrm{X}$ \\
\hline Cetopsorhamdia iheringi & $\mathrm{X}$ & $\mathrm{X}$ & $\mathrm{X}$ \\
\hline Characidium zebra & & & $\mathrm{X}$ \\
\hline Eigenmannia cf. trilineata & & & $\mathrm{X}$ \\
\hline Geophagus brasiliensis & & & $\mathrm{X}$ \\
\hline Gymnotus carapo & & & $\mathrm{X}$ \\
\hline 'Heptapterus' sp. & $\mathrm{X}$ & & \\
\hline Imparfinis sp. & & & $\mathrm{X}$ \\
\hline Knodus moenkhausii & $\mathrm{X}$ & $\mathrm{X}$ & $\mathrm{X}$ \\
\hline Oligosarcus argenteus & $\mathrm{X}$ & & \\
\hline Oligosarcus paranensis & & & $\mathrm{X}$ \\
\hline Pareiorhina hyptiorhachis & $\mathrm{X}$ & $\mathrm{X}$ & \\
\hline Piabarchus stramineus & & & $\mathrm{X}$ \\
\hline Piabina argentea & & & $\mathrm{X}$ \\
\hline Pimelodella gracilis & & & $\mathrm{X}$ \\
\hline Pimelodus maculatus & & & $\mathrm{X}$ \\
\hline Poecilia vivipara & & & $\mathrm{X}$ \\
\hline
\end{tabular}

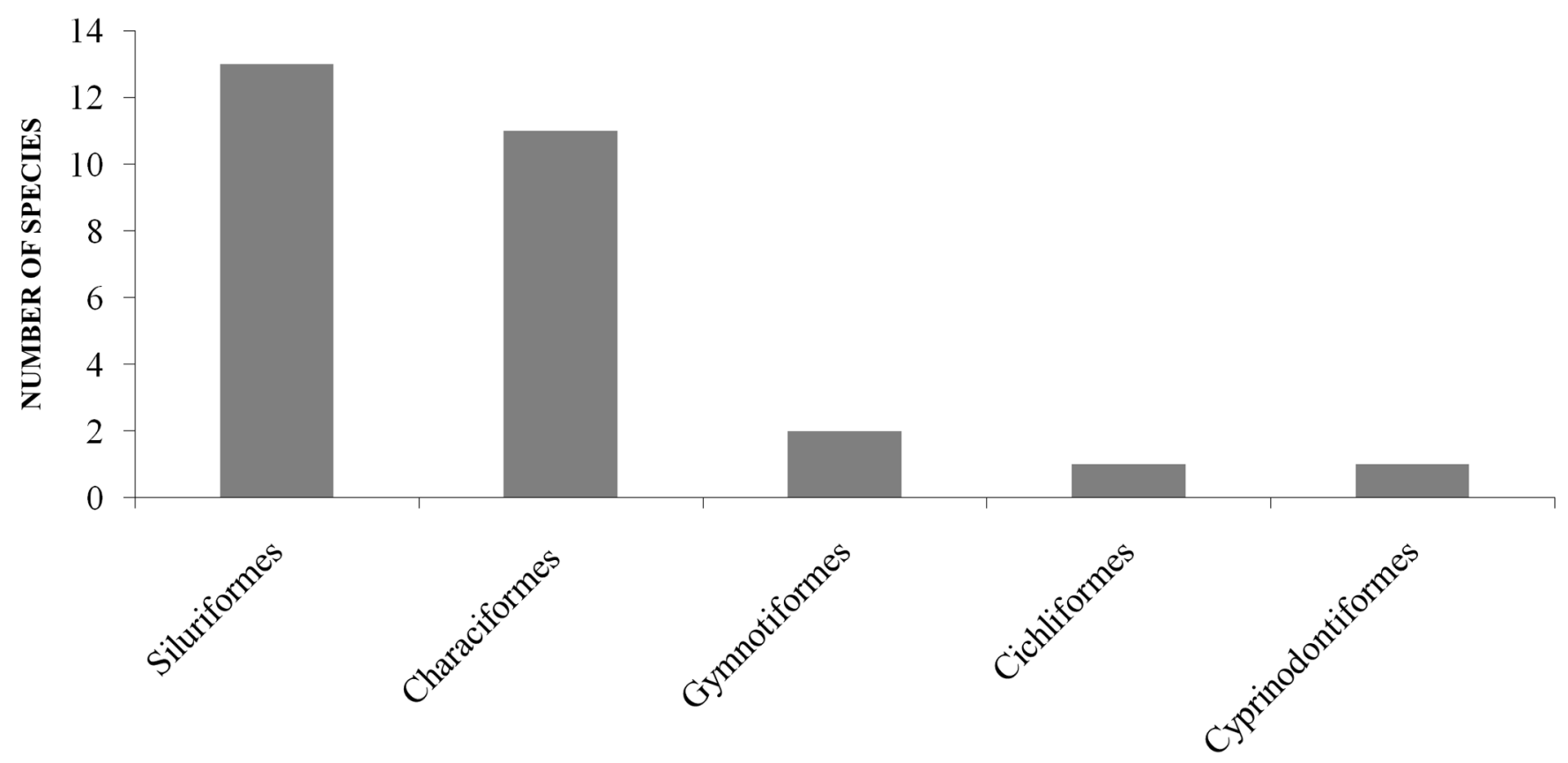

ORDERS

Figure 3. Species richness by orders collected in reaches of three different streams of the Rio Sapucaí basin, Minas Gerais, Brazil. 


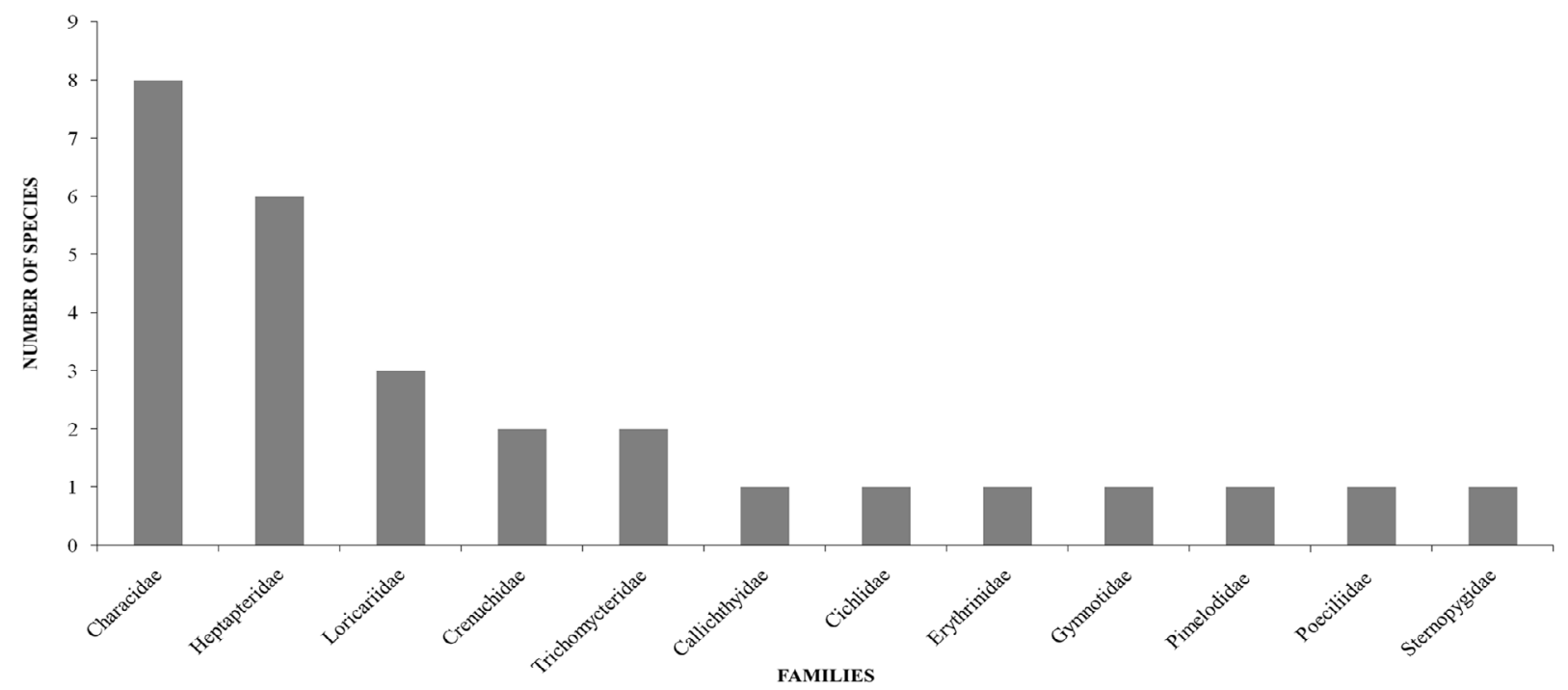

Figure 4. Species richness by families collected in reaches of three different streams of the Rio Sapucaí basin, Minas Gerais, Brazil.
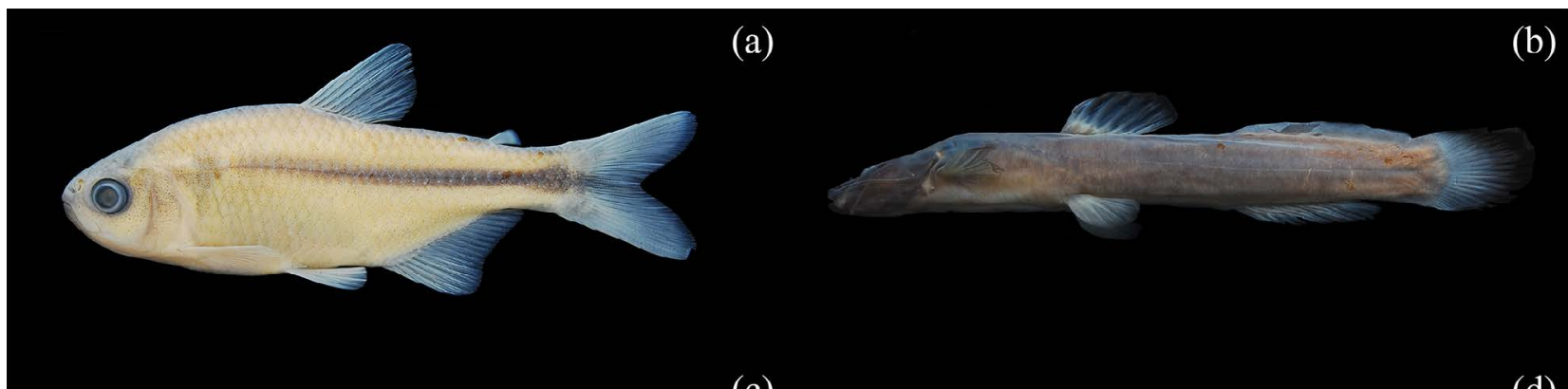

(c)

(d)
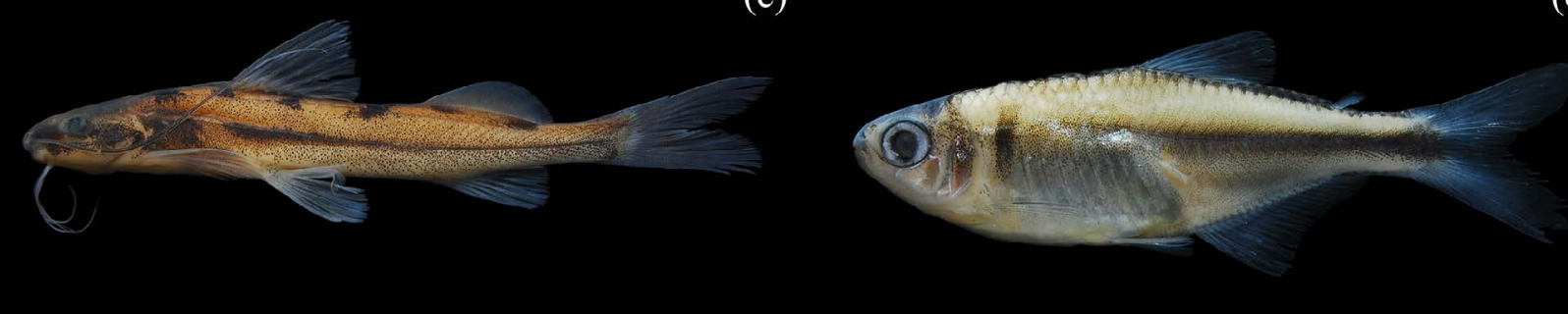

(e)
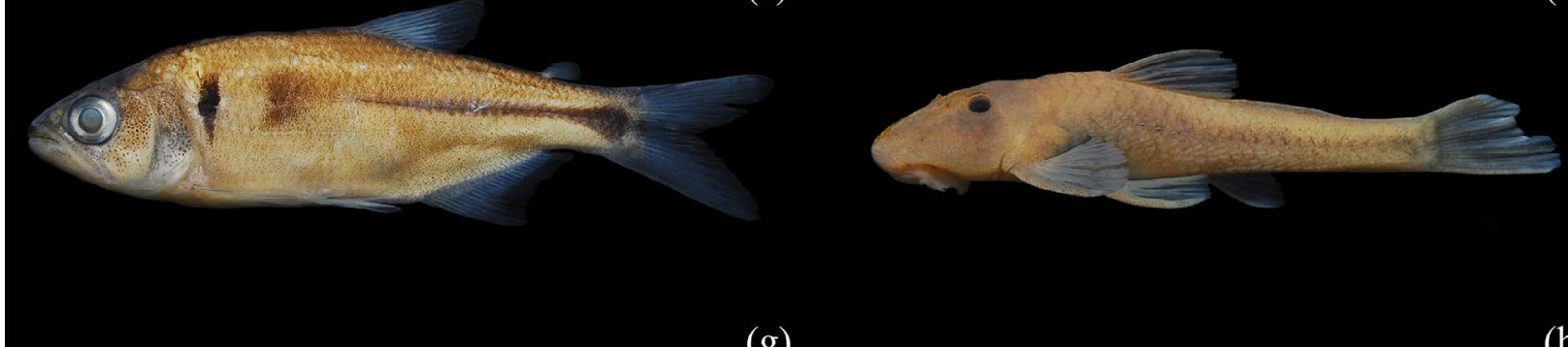

$(\mathrm{g})$

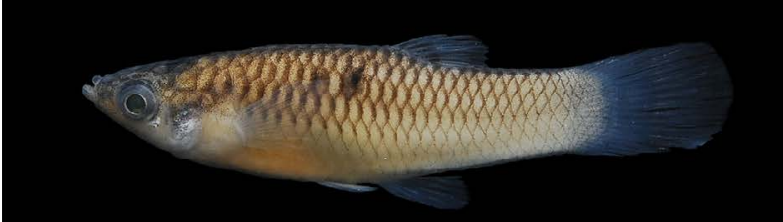

Figure 5. Representative individuals of eight species collected in this study: (a) Astyanax sp., 43.9 mm SL, LBP 26571; (b) 'Heptapterus' sp., 104.8 mm SL, LBP 23577; (c) Imparfinis sp., 58.7 mm SL, LBP 26600; (d) Knodus moenkhausii, 34.5 mm SL, LBP 26584; (e) Oligosarcus argenteus, 61.8 mm SL, LBP 23572; (f) Pareiorhina hyptiorhachis, 28.5 mm SL, LBP 26572; (g) Poecilia vivipara, 29.6 mm SL, LBP 26610; (h) Trichomycterus septemradiatus, 39.6 mm SL, LBP 26573. 
Trichomycterus septemradiatus (Figure 5h) was previously known only from its type locality, a single stream in the Rio Sapucaí basin (Katz et al. 2013). Our study reports individuals of $T$. septemradiatus at $\mathrm{R} 1$; therefore, we extend the distribution of this species within the basin.

Individuals of two non-native species, Knodus moenkhausii and Poecilia vivipara, were collected in this survey (see Table 3). Knodus moenkhausii (Figure 5d) has previously been assigned by different authors as non-native to the upper Rio Paraná system (e.g., Langeani et al. 2007, Souza et al. 2015, Azevedo-Santos et al. 2018b). Poecilia vivipara (Figure $5 \mathrm{~g}$ ) has also been reported by Langeani et al. (2007) as a non-native species introduced to the upper Rio Paraná system. Therefore, we consider K. moenkhausii and $P$. vivipara as non-native species within the Rio Sapucai basin (sensu Langeani et al. 2007). However, sources of these introductions remain unknown.

Here we contribute to the knowledge of the fish fauna of the Rio Sapucaí basin, upper Paraná system. However, we recognize this study likely represents a small fraction of what remains to be sampled within this basin. The presence of putative undescribed species coupled with increasing anthropogenic effects highlights the need to conduct more surveys of the ichthyofauna of waterbodies of this region.

\section{Acknowledgments}

We are grateful to: Flávio A. Bockmann, for the identification of Imparfinis sp., Imparfinis schubarti, and Pimelodella gracilis; Naércio A. Menezes, for help with the identification of Oligosarcus argenteus; and Carlos A. M. Oliveira, for confirmation of the identification of Astyanax sp. We also would like to thank: Francisco Langeani, for curatorial assistance; Paula N. Coelho, for help with collections, suggestions on this manuscript, and logistical support; Pedro S. Manoel and Brandon T. Waltz, for comments and corrections in the first draft of this manuscript; and Isabel M Soares, for help with photos of the Figure 5. We also wish thanks to Ana Claudia Santos, for the valuable suggestions on this manuscript. VMAS was supported by Coordenação de Aperfeiçoamento de Pessoal de Nivel Superior (CAPES). HAB, CO, and RCB were supported by Conselho Nacional de Desenvolvimento Científico e Tecnológico (CNPq).

\section{Author Contributions}

Valter M. Azevedo-Santos: idealized the survey and collected all individuals; identified fish species; wrote this manuscript.

Heraldo A. Britski: identified fish species; wrote this manuscript.

Claudio Oliveira: wrote this manuscript.

Ricardo C. Benine: wrote this manuscript.

\section{Conflicts of interest}

The authors declare that they have no conflict of interest related to the publication of this manuscript.

\section{References}

AZEVEDO-SANTOS, V.M., FREDERICO, R.G., FAGUNDES, C.K., POMPEU, P.S., PELICICE, F.M., PADIAL, A.A., NOGUEIRA, M.G., FEARNSIDE, P.M., LIMA, L.B., DAGA, V.S., OLIVEIRA, F.J.M., VITULE, J.R.S., CALLISTO, M., AGOSTINHO, A.A., ESTEVES, F.A., LIMA-JUNIOR, D.P., MAGALHÃES, A.L.B., SABINO, J., MORMUL, R.P., GRASEL, D., ZUANON, J., VILELLA, F.S. \& HENRY, R. 2018a. Protected areas: A focus on Brazilian freshwater biodiversity. Divers. Distrib., https://doi.org/10.1111/ddi.12871

AZEVEDO-SANTOS, V.M., COELHO, P.N. \& DEPRÁ, G.C. 2018b. Ichthyofauna of the Ribeirão Frutal and tributaries, upper Rio Paraná basin, Minas Gerais, Southeastern Brazil. Biota Neotrop. 18(3): e20180517. http:// dx.doi.org/10.1590/1676-0611-BN-2018-0517

BELEI, F., SAMPAIO, W.M.S. 2012. Ictiofauna do rio Lourenço Velho, afluente do Rio Grande: pequena diversidade, grande importância para a conservação de uma espécie ameaçada. Evol. Conserv. Biodivers., 3: 14-27.

BERTORA, A., GROSMAN, F., SANZANO, P., ROSSO, J.J. 2018. Fish fauna from the Langueyú basin, Argentina: a prairie stream in a heavily modified landscape. Check List 14 (2): 461-470. https://doi.org/10.15560/14.2.461

CASATTI, L., LANGEANI, F. \& CASTRO, R. M. C. 2003. Peixes de riacho do Parque Estadual Morro do Diabo, bacia do alto rio Paraná, SP. Biota Neotrop. 1: - http://www.biotaneotropica.org.br/v1n12/pt/abstract?invent ory+BN00201122001

CAVALLI, D., FROTA, A., LIRA, A. D., GUBIANI, E. A., MARGARIDO, V. P. \& GRAÇA, W. J. 2018. Update on the ichthyofauna of the Piquiri River basin, Paraná, Brazil: a conservation priority area. Biota Neotrop. 18(2): e20170350. http://dx.doi.org/10.1590/1676-0611-BN-2017-0350

CHUCTAYA, J., BÜHRNHEIM, C.M. \& MALABARBA, L.R. 2018. Two new species of Odontostilbe historically hidden under O. microcephala (Characiformes: Cheirodontinae). Neotrop. Ichthyol. 16: e170047. http:// dx.doi.org/10.1590/1982-0224-20170047

DELARIVA, R. L., NEVES, M. P., LARENTIS, C., KLIEMANN, B. C. K., BALDASSO, M. C. \& WOLFF, L. L. 2018. Fish fauna in forested and rural streams from an ecoregion of high endemism, lower Iguaçu River basin, Brazil. Biota Neotrop.18(3): e20170459. http://dx.doi.org/10.1590/16760611-BN-2017-0459

FAGUNDES, D.C., LEAL, C.G., CARVALHO, D.R., JUNQUEIRA, N.T., LANGEANI, F. \& POMPEU, P.S. 2015. The stream fish fauna from three regions of the Upper Paraná River basin. Biota Neotrop. 15(2): e20140187. http://dx.doi.org/10.1590/1676-06032015018714

FRICKE, R., ESCHMEYER, W. N. \& FONG, J. D. 2018. SPECIES BY FAMILY/SUBFAMILY. (http://researcharchive.calacademy.org/research/ ichthyology/catalog/SpeciesByFamily.asp). (last access 30 October 2018).

FROTA, A., DEPRÁ, G.C., PETENUCCI, L.M. \& GRAÇA, W.J. 2016. Inventory of the fish fauna from Ivaí River basin, Paraná State, Brazil. Biota Neotrop.16(3): e20150151. http://dx.doi.org/10.1590/1676-0611-BN-2015-0151

HONORIO, J. R. \& MARTINS, I. A. 2018. Ichthyofauna of the Una river in the Paraíba do Sul Paulista River Valley, Southeastern of Brazil. Biota Neotrop. 18(4): e20180528. http://dx.doi.org/10.1590/10.1590/1676-0611-BN-2018-0528

INGENITO, L.F.S. \& BUCKUP P.A. 2007. The Serra da Mantiqueira, southeastern Brazil, as a biogeographical barrier for fishes. J. Biogeogr. 34: 1173-1182. https://doi.org/10.1111/j.1365-2699.2007.01686.x

KATZ, A.M., BARBOSA, M.A., COSTA, W.J.E.M. 2013. Two new species of the catfish genus Trichomycterus from the Paraná river basin, southeastern Brazil (Teleostei: Trichomycteridae). Ichthyol. Explor. Freshw. 23 (4): 359-366.

LANGEANI, F., CASTRO, R.M.C., OYAKAWA, O.T., SHIBATTA, O.A., PAVANELLI, C.S. \& CASATTI, L. 2007. Diversidade da ictiofauna do Alto Rio Paraná: composição atual e perspectivas futuras. Biota Neotrop. 7: 181-197. http://www.biotaneotropica.org.br/v7n3/pt/abstract?article+bn03407032007

MAGALHÃES JR., A.P. \& DINIZ, A.A. 1997. Padrões e direções de drenagem na Bacia do Sapucaí - Sul de Minas Gerais. Geonomos 5: 29-32 
MELO, B.F., BENINE, R.C., BRITZKE, R., GAMA, C.S. \& OLIVEIRA, C. 2016. An inventory of coastal freshwater fishes from Amapá highlighting the occurrence of eight new records for Brazil. ZooKeys 606: $127-140$

OLIVEIRA-SILVA, L., RAMOS, T. P. A., CARVALHO-ROCHA, Y. G. P., VIANA, K. M. P., AVELLAR, R. C. \& RAMOS, R. T. C. 2018. Ichthyofauna of the Mamanguape river basin, Northeastern, Brazil. Biota Neotrop. 18(3): e20170452. http://dx.doi.org/10.1590/1676-0611$\mathrm{BN}-2017-0452$

PELICICE, F.M., AZEVEDO-SANTOS, V.M., VITULE, J.R.S., ORSI, M.L., LIMA-JUNIOR, D.P., MAGALHÃES, A.L.B., POMPEU, P.S., PETRERE JR, M. \& AGOSTINHO, A.A. 2017. Neotropical freshwater fishes imperilled by unsustainable policies. Fish Fish. 18 (6):1119-1133. https:// doi.org/10.1111/faf.12228

RIBEIRO, A.C. \& MENEZES, N.A. 2015. Phylogenetic relationships of the species and biogeography of the characid genus Oligosarcus Günther, 1864 (Ostariophysi, Characiformes, Characidae). Zootaxa 3949 (1): 041-081. http://dx.doi.org/10.11646/zootaxa.3949.1.2

SANTOS, A.C., GONÇALVES, C.C. \& CARVALHO, F.R. 2017. Ichthyofauna of the "Cachoeira de São Roberto" and fishes of lower Preto River, upper Paraná River basin, Brazil. Biota Neotrop. 17(1): e20160196. http://dx.doi. org/10.1590/1676-0611-BN-2016-0196
SILVA, G.S.C., ROXO, F.F. \& OLIVEIRA, C. 2013. Pareiorhina hyptiorhachis, a new catfish species from Rio Paraíba do Sul basin, southeastern Brazil (Siluriformes, Loricariidae). ZooKeys 315: 65-76. https://doi.org/10.3897/zookeys.315.5307

SMITH, W.S., \& PETRERE JR, M. 2007. Fish, Itupararanga Reservoir, Sorocaba River Drainage, São Paulo, Brazil. Check List 2007: 3(2). http://dx.doi. org/10.15560/3.2.131

SMITH, W.S., PETRERE JR, M. \& BARRELLA, V. 2007. Fishes, Sorocaba river sub-basin, State of São Paulo, Brazil. Check List 3(3): 282-286. https:// biotaxa.org/cl/article/view/3.3.282/13429

SOUZA, C. S., OLIVEIRA, C. \& PEREIRA, L. H. G. 2015. Knodus moenkhausii (Characiformes: Characidae): one fish species, three hydrographic basins a natural or anthropogenic phenomenon? DNA Barcodes, 3: 129-138. DOI: 10.1515/dna-2015-0016

VALDIVIEZO-RIVERA, J., CARRILLO-MORENO, C. \& GEA-IZQUIERDO, E. 2017. Annotated list of freshwater fishes of the Limoncocha Lagoon, Napo river basin, northern Amazon region of Ecuador. Check List 14 (1): 55-75. https://doi.org/10.15560/14.1.55

Received: $19 / 07 / 2018$

Revised: $24 / 09 / 2018$

Accepted: 30/11/2018

Published online: 04/02/2019 